\title{
INTENSITAS SYARIAH DALAM NEGARA BERDASAR ATAS KETUHANAN YANG MAHA ESA
}

\author{
Arlis \\ Fakultas Syariah IAIN Imam Bonjol Padang \\ Jl. M. Yunus Lubuk Lintah Padang \\ e-mail: arlis.antiko@gmail.com
}

\begin{abstract}
Sharia is the law of God. The intensity of the Shari'ah refers to the conditio sin qua non for the good sake of mankind. Moreover, the state principles of Indonesia clearly mentions that this country believes in God the Almighty. However, the facts show that the Shari'ah has not become the soul of way of life of the nation. In fact, the concept of Shariah itself in some contemporary Islamic discussions is debatable due to its narrow and improper definition. Consequently debates concerning with the implementation leads serious problems. This article aims at elaborating the concept of Sharia intensity, existence, and its implementation in a state that bases its believe in God the Almighty through philosophical, legal and sociological approaches.
\end{abstract}

Kata kunci: intensitas syariah, negara, Ketuhanan Yang Maha Esa

\section{PENDAHULUAN}

$S$ yariah cocok untuk semua waktu dan tempat (Syariah-salihun li kulli zaman wa makan). Sebab syariah adalah produk Tuhan Yang Maha Kuasa terhadap semua waktu dan tempat tersebut. Tuhan sudah memaklumkan bahwa: "Bagi tiap-tiap umat telah Kami tetapkan syari'at tertentu yang mereka lakukan, maka janganlah sekali-kali mereka membantah kamu dalam urusan (syari'at) ini dan serulah kepada (agama) Tuhanmu. Sesungguhnya kamu benarbenar berada pada jalan yang lurus (terjemah Firman Tuhan Q.S. Al-Hajj [22]: 67).

Berdasarkan informasi Tuhan di atas, dapat dimaklumi bahwa syariah dan intensitasnya merupakan conditio sin qua non bagi keselamatan hidup umat manusia. Syariah ditetapkan oleh Tuhan supaya menjadi rahmat bagi alam semesta (rahmatan lil'alamin). Satu-satunya jalur keselamatan seluruh manusia pada setiap generasi sepanjang sejarahnya hanya melalui syariah.

Idealitas syariah yang secara langsung telah digaransi oleh Tuhan menjadi problema di tengah-tengah umat manusia. Problema sepertinya sudah sangat kronis, sampai-sampai terminologi syariah itu masih ada yang menyebutkan telah menimbulkan kerancuan serius. Terminologi syariah, menurut kajian Islam kontemporer, telah menimbulkan kerancuan serius, jika terminologi syariah dikaji dalam pengertian sempit dan pada proporsi kajian Hukum (Syafaul Mudawam, 2012:403). Pendapat lain mengatakan bahwa belum ada suatu kesepakatan di kalangan mereka tentang makna syariat itu sendiri (Yusdani, 206:197).

Reintroduksi Syariah adalah tujuan lama bagi gerakan Islam di negara-negara Muslim, meskipun upaya untuk menegakkan Syariah telah disertai dengan 
berbagai kontroversi, kekerasan, dan bahkan peperangan beberapa negera seperti pada Sudan dengan Perang Sipil. Beberapa di Afrika Utara dan negaranegara lain di Asia hanya mempertahankan pengakuan kelembagaan syariah, dan mempertahankannya untuk mengadili dalam urusan masyarakat muslim. Di negara-negara Barat di mana imigran Muslim yang datang lebih kemudian sebagai minoritas, telah memperkenalkan syariah tentang hukum keluarga untuk digunakan dalam perselisihan mereka sendiri, seperti Pengadilan Arbitrase Muslim Inggris. (Syafaul Mudawam, 2012: 411).

Negara-negara Muslim seperti Mali, Kazakhstan, dan Turki, berada di bawah tekanan dari partai politik agama, telah menyatakan diri untuk menjadi sekuler. Di sini, campur tangan agama dalam urusan negara, hukum dan politik adalah dilarang. Di negara-negara muslim sekuler serta negara Barat, peran syariah terbatas pada hal-hal pribadi dan keluarga. Negara-negara Muslim, termasuk Pakistan, Indonesia, Afghanistan, Mesir, Nigeria, Sudan, Maroko dan Malaysia memiliki sistem hukum sangat dipengaruhi oleh syariah, tetapi juga menyerahkan wewenang tertinggi konstitusi dan aturan hukum kepada negara. Arab Saudi dan beberapa negara Teluk tidak memiliki konstitusi atau legislatif, Penguasa mereka memiliki kewenangan terbatas untuk mengubah undang-undang, karena mereka didasarkan pada Syariah seperti yang ditafsirkan oleh Ulama mereka. Iran dengan beberapa karakteristik, adalah negara yang memiliki legislasi parlemen, tetapi juga konsisten dengan cara yang disebut oleh syariah. (Syafaul Mudawam, 2012: 411412)
Untuk kasus Negara Indonesia, berdasarkan rumusan dalam konstitusi sejauh penelusuran penulis- Indonesia adalah satu-satunya Negara di dunia yang menyebutkan Negara berdasar atas Ketuhanan Yang Maha Esa. Dari segi kuantitas penganut agama, Indonesia adalah negara muslim terbesar di seluruh dunia. Namun di mata negara-negara Islam, Indonesia sering diposisikan sebagai negara sekuler (Nur Rohim Yunus, 2015: 254). Oleh sebab itu, menjadi sangat urgen dan menarik untuk dikaji bagaimana intensitas syariah dalam Negara berdasar atas Ketuhanan Yang Maha Esa.

Tulisan ini bertujuan untuk mengetahui intensitas Syariah dalam Negara berdasar atas Ketuhanan Yang Maha Esa.

Ruang lingkup tulisan ini menguraikan tentang konsepsi intensitas syariah, eksistensi syariah dan penerapannya, intensitas syariah pada negara berdasar atas Ketuhanan Yang Maha Esa. Pendekatan kajian dengan memvariasikan pendekatan filosofis, yuridis, dan sosiologis.

\section{PEMBAHASAN}

\section{Konsepsi Intensitas Syariah}

Intensitas syariah merupakan suatu konsepsi yang tersusun dari dua kata, yaitu kata intensitas dan hukum. Kata intensitas (intensity dalam bahasa Inggris, kasafah dalam bahasa Arab, dan intensiteit dalam bahasa Belanda): keadaan tingkatan atau ukuran intensnya (Departemen Pendidikan Nasional, 2003: 438). Sedangkan kata syariah (syariat): hukum agama yang menetapkan peraturan hidup manusia, hubungan manusia dengan Allah Swt, 
hubungan manusia dengan manusia dan alam sekitar berdasarkan alquran dan hadis (Departemen Pendidikan Nasional, 2003: 1115). Berdasarkan pengertian masing-masing kata tersebut, pengertian intensitas syariah adalah keadaan tingkatan atau ukuran intens hukum agama yang menetapkan peraturan hidup manusia, hubungan manusia dengan Allah Swt, hubungan manusia dengan manusia dan alam sekitar berdasarkan alquran dan hadis.

Sangat menarik untuk dijadikan dasar kajian ketika ditemukan dalam Alquran terjemah begitu banyaknya kata hukum dibandingkan kata syariah, bahkan kata syariah tidak ditemukan sama sekali. Hal ini dapat dilihat pada tabel berikut:

Tabel 1.

Kata Syariat, Syariah dan Hukum dalam Alquran

\begin{tabular}{|c|c|c|c|c|}
\hline \multirow[b]{2}{*}{ NO } & \multirow[b]{2}{*}{ KATA } & \multirow[b]{2}{*}{ SURAT } & \multicolumn{2}{|c|}{ JUMLAH } \\
\hline & & & Surat & Ayat \\
\hline 1 & Syariat/Syari'at & 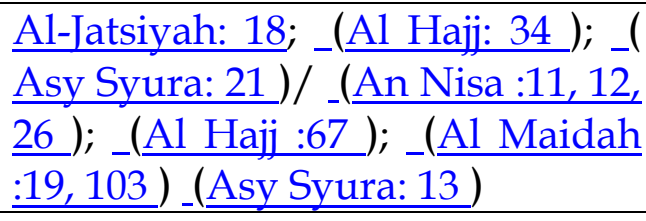 & $3 / 4$ & $3 / 7$ \\
\hline 2 & Syariah & - & & - \\
\hline 3 & Hukum & 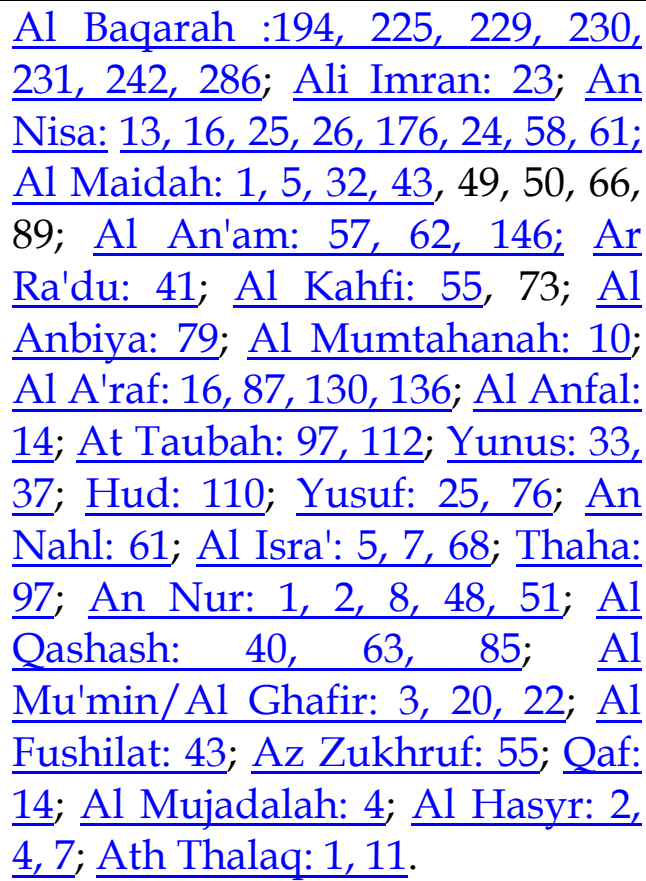 & 27 & 69 \\
\hline
\end{tabular}

Sumber: Diolah dari website Alquranterjemah.com

Berdasarkan data di atas, secara kuantitas diketahui bahwa penggunaan istilah atau kata hukum sangat dominan dalam Alquran. Oleh sebab itu, melalui pendekatan intensitas, menggunakan kata hukum tanpa embel-embel apapun sudah 
sesuai dengan ketentuan Tuhan Yang Maha Esa. Dengan perkataan lain, kata hukum ada pada jalur yang sama dengan syariah atau syariat, atau pun istilah lainnya. Sebab istilah tersebut bisa berkembang jauh lebih banyak sesuai dengan bahasa masyarakat di berbagai penjuru dunia.

\section{Eksistensi Syariah dan Penerapannya}

Berdasarkan konsepsi intensitas syariah sebelumnya, maka dapat dimaklumi bahwa eksistensi syariah mesti diakui keberadaannya.

Alur eksistensi syariah adalah dari Allah untuk makhluk, dan akhirnya kembali kepada Allah. Jika alur syariah dikhususkan bagi manusia maka gambarannya adalah syariah dari Allah, diajarkan oleh para Nabi dan Rasul, diwarisi oleh Ulama untuk diajarkan kepada seluruh umat manusia di mana pun berada.

Syariah mencakup keyakinan dan praktek. Syariah berisikan ibadat serta sikap perilaku individual, berisikan norma-norma dan bidang hukum, baik politik, ekonomi, kekeluargaan, maupun hukum kriminal atau sipil. Syariah kadang-kadang diartikan secara khusus sebagai ketentuan yang menyangkut suruhan dan larangan yang mengatur sikap dan tingkah laku. Selain itu, syariah juga diartikan sebagai hukum Islam secara khusus, baik yang membutuhkan kekuatan Negara untuk pelaksanaannya atau tidak membutuhkannya.

Berkenaan dengan Nabi dan Rasul, Tuhan memberikan syariat kepada Adam dan seterusnya sampai kepada Nabi Muhammad Saw. (Rifyal Ka'bah, 2005: 102-103). Pembicaraan tentang intensitas masing-masingnya membutuhnya waktu yang sangat lama dan tulisan yang berkesinambungan. Oleh sebab itu, berikut ini hanya disebutkan beberapa informasi dari Rasulullah Saw. dalam kaitannya dengan syariah dan intensitasnya, yaitu:

1. Musnad Ahmad 15075:

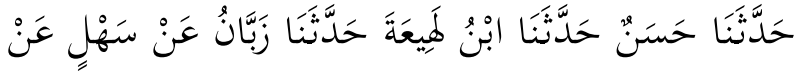

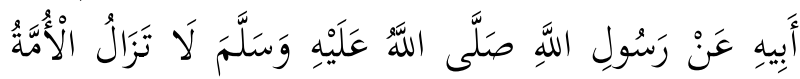

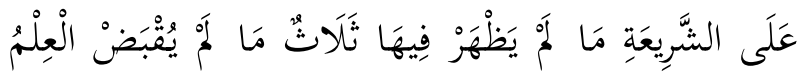

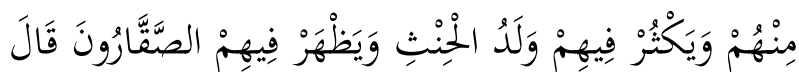

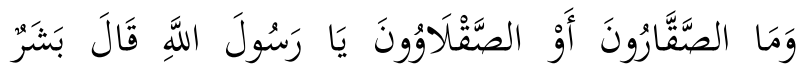

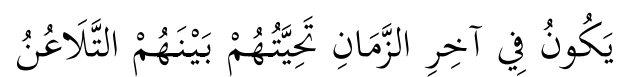

Telah menceritakan kepada kami Hasan telah menceritakan kepada kami Ibnu Lahi'ah telah menceritakan kepada kami Zabban dari Sahl dari Bapaknya dari Rasulullah Shallallahu'alaihiwasallam, "Umat Islam akan tetap berada di atas syariat selama tidak muncul tiga hal di kalangan mereka: Selama ilmu belum dicabut, banyak dijumpai pada mereka anak-anak orang banci, dan muncul shaqqarun. Ada yang bertanya 'Apa maksud shaqqarun atau shaqlawun itu Wahai Rasulullah?. Beliau menjawab, manusia yang hidup di akhir zaman sedang kata sapaan di antara mereka saling melaknat".

Riwayat di atas memberikan informasi tentang konsistensi umat berada di atas syariah selama tidak muncul tiga hal di tengah-tengah mereka, yaitu: pertama, ilmu belum dicabut; kedua, banyak dijumpai pada mereka anak-anak orang banci; dan ketiga, muncul shaqqarun.

2. Sunan Ibnu Majah 2543:

Telah menceritakan kepada kami Abu Bakar bin Abu Syaibah dan Muhammad bin Shabah, keduanya berkata; telah 
menceritakan kepada kami Sufyan bin Uyainah dari Az Zuhri dari Ubaidullah bin Abdullah bin Utbah dari Ibnu Abbas, ia berkata, Umar bin Khaththab berkata; "Aku khawatir setelah lama masa berlalu, hingga seseorang berkata, "Tidak aku temukan hukum rajam di dalam kitabullah (Alquran), hingga mereka akan sesat karena meninggalkan salah satu dari syari'at Allah. Ingatlah! Sesungguhnya hukum rajam benar adanya. Apabila terjadi zina lalu ada saksi atau wanita yang bersangkutan hamil, atau ada pengakuan, maka aku membaca, "Laki-laki dan wanita dewasa apabila keduanya berzina, maka benar-benar rajamlah mereka." Rasulullah shallallahu 'alaihi wasallam melakukan hukum rajam dan kami pun melaksanakannya sepeninggal beliau.

Riwayat di atas secara jelas memberitahukan tentang terjadinya di suatu masa banyak manusia yang sesat karena meninggalkan syariah.

3. Musnad Ahmad 13919:

Telah bercerita kepada kami Abdurrazaq telah mengkhabarkan kepada kami Ma'mar dari Ibnu Khutsaim dari Abdurrahman bin Sabith dari Jabir bin Abdullah Sesungguhnya Nabi shallallahu 'alaihi wasallam bersabda kepada Ka'b bin' Ujrah, "Semoga Allah melindungimu dari pemerintahan orang-orang yang bodoh", (Ka'b bin 'Ujrah Radliyallahu'anhu) bertanya, apa itu kepemerintahan orang bodoh? (Rasulullah shallallahu 'alaihi wasallam) bersabda: "Yaitu para pemimpin negara sesudahku yang tidak mengikuti petunjukku dan tidak pula berjalan dengan Sunnahku, barangsiapa yang membenarkan mereka dengan kebohongan mereka serta menolong mereka atas kezaliman mereka maka dia bukanlah golonganku, dan aku juga bukan termasuk golongannya, mereka tidak akan datang kepadaku di atas telagaku, barang siapa yang tidak membenarkan mereka atas kebohongan mereka, serta tidak menolong mereka atas kezaliman mereka maka mereka adalah golonganku dan aku juga golongan mereka serta mereka akan mendatangiku di atas telagaku. Wahai Ka'b bin 'Ujrah puasa adalah perisai, sedekah memadamkan api neraka dan shalat adalah persembahan. Atau beliau bersabda: penerang. Wahai $K a ' b$ bin Ujrah sesungguhnya tidak akan masuk syurga daging yang tumbuh dari hal yang dimurkai Allah (haram), dan neraka adalah paling tepat untuknya, Wahai Ka'b bin 'Ujrah manusia berpagi dengan dua keadaan; yaitu ia terjual dirinya kemudian ia membebaskannya atau ia menjual dirinya kemudian ia menghancurkan dirinya.

Beberapa kutipan Sunnah Rasulullah sebelumnya dengan sangat terang dan nyata menunjukkan pentingnya intensitas syariah.

\section{Intensitas Syariah pada Negara Berdasar Atas Ketuhanan Yang Maha Esa}

Intensitas syariah pada Negara berdasar Atas Ketuhanan Yang Maha Esa ditinjau secara filosofis sangat ideal dan penting dipertahankan. Karena akal sebagai media berpikir filosofis adalah ciptaan Tuhan Yang Maha Esa itu sendiri, begitu juga dengan negara. Oleh sebab itu, secara filosofis idealnya akal warga dalam Negara berdasar atas Ketuhanan Yang Maha Esa secara mutlak melahirkan pemikiran filosofis bahwa syariah merupakan standar nilai dan standar operasional kehidupan berbangsa dan bernegara dalam berbagai aspeknya. Syariah adalah sumber atau sesuatu yang esensial dalam kehidupan. Dengan syariah, maka kehidupan menjadi berarti di hadapan Allah dan masyarakat (Rifyal 
Ka'bah, 2005: 102).

Berkaitan dengan hal ini, sangat banyak informasi yang datang dari Tuhan Yang Maha Esa itu sendiri. Di antara informasi dimaksud seperti Firman Tuhan Yang Maha Esa dalam surat Al-Jatsiyah Ayat ke-18 yang berarti: kemudian kami menjadikan kalian dalam urusan berdasarkan sebuah syariah, maka ikutilah syariah tersebut dan jangan ikuti hanya nafsu orang-orang yang tidak berpengetahuan.

Kesepakatan the founding father and mother negara Indonesia menempatkan Ketuhanan Yang Maha Esa sebagai dasar utama Negara menunjukkan bahwa syariah merupakan puncak dari intensitas bernegara. Jalur kehidupan yang dituju oleh bangsa dan Negara ini adalah diterapkannya syariah secara kaffah (total). Tanpa penerapan syariah, eksistensi Negara tidak memiliki makna dalam artian yang sesungguhnya.

Secara Yuridis dan konstitusional kalimat Negara berdasar atas Ketuhanan Yang Maha Esa merupakan salah satu ketentuan yang terdapat dalam UndangUndang Dasar Negara Republik Indonesia Tahun 1945. Ketika dihubungkan dengan ketentuan-ketentuan lain yang terdapat dalam UUD yang sama, maka terdapat kesesuaian dan sinkronisasi. Berdasarkan hal tersebut dapat dikatakan bahwa UUD menghendaki syariah sebagai ukuran intensitas kehidupan berbangsa dan bernegara dalam segala aspeknya.

Makna yang terkandung dalam kalimat Ketuhanan Yang Maha Esa (alRabbaniyyah al-Mutafarridah) adalah tauhid uluhiyyah, tauhid rububiyyah, dan tauhid asma' wa shifat. Islam tidak mengenal Tuhan selain Allah. Siapa saja yang mengenal dan meyakini ada Tuhan selain Allah, orang tersebut sungguh sudah menserikatkan Tuhan (syirik). Pemahaman dan keyakinan tentang Ketuhanan Yang Maha Esa adalah prinsip utama dari semua prinsip yang terdapat dalam Islam (Muhammad ibn Nasir al-Abudi, 2000: 62).

Ketentuan Ketuhanan Yang Maha Esa sesuai dengan surat al-Ikhlas dan sejalan dengan Ilmu tauhid. Dengan ketentuan Ketuhanan Yang Maha Esa ini, bangsa Indonesia memaklumkan keimanan kepada Allah dan kewajiban bertaqwa kepada-Nya. Juga tentang jalan Islam bersamaan dengan keikutsertaan agama lain. Adanya saling menghormati perbedaan. Begitu juga dengan kebebasan untuk menjalankan ajaran agama masingmasing. Hal ini adalah mafhum akhir didasarkan pada firman Allah la ikraha fi addin (Muhammad Ibn Nasir al-Abudi, 2000: 68).

Berdasarkan kepada UndangUndang Nomor 12 Tahun 2011 Tentang Pembentukan Peraturan PerundangUndangan diketahui adanya aturan tentang sistematika dan kerangka peraturan perundang-undangan yang harus memuat Frasa Dengan Rahmat Tuhan Yang Maha Esa dalam pembukaan. Dalam Undang-undang tersebut disebutkan bahwa pada pembukaan tiap jenis Peraturan Perundang-undangan sebelum nama jabatan pembentuk Peraturan Perundang-undangan dicantumkan Frasa Dengan Rahmat Tuhan yang Maha Esa yang ditulis seluruhnya dengan huruf kapital yang diletakkan di tengah marjin. Ketika ketentuan ini dimaknai dengan benar maka diketahui intensitasnya bahwa pembentukan seluruh peraturan perundang-undangan di Indonesia didasarkan dengan rahmat Tuhan Yang Maha Esa. Maka intensitas maknanya adalah ketika aturan dimuat dengan rahmat Tuhan, maka aturan yang dibuat 
itu pasti sejalan dengan aturan Tuhan. Tidak memungkinkan sama sekali terbuka peluang dalam aturan tersebut ada yang bertentangan dengan aturan Tuhan. Ketika hal yang terakhir ini terjadi perumusan peraturan perundangundangan tidak ubahnya melestarikan perilaku kemunafikan, lain kata dengan perbuatan.

Mesti menjadi renungan segenap elemen bangsa, bahwa hanya dengan intensitas penerapan syariah- Negara dapat melaksanakan misi luhurnya membentuk suatu Pemerintah Negara Indonesia yang melindungi segenap bangsa Indonesia dan seluruh tumpah darah Indonesia dan untuk memajukan kesejahteraan umum, mencerdaskan kehidupan bangsa, dan ikut melaksanakan ketertiban dunia yang berdasarkan kemerdekaan, perdamaian abadi dan keadilan sosial.

Secara historis sosiologis, Semangat untuk menegakkan syariat Islam di Indonesia tampaknya tidak pernah padam. Hal ini tampak dari sejarah pergulatan politik nasional. Memang syariat Islam telah menjadi sejarah bangsa Indonesia. Semenjak Islam masuk ke negeri ini, kerajaan-kerajaan Islam senantiasa berusaha untuk menegakkan syariat di daerahnya. Setelah penjajahan Belanda berkuasa pun, kerajaan-kerajaan Islam yang ada masih berusaha menegakkannya, walaupun secara berangsur-angsur hukum Barat ataupun adat diterapkan. Namun pergerakan nasional yang bersifat Islam menempatkan penegakan syariat Islam sebagai cita-cita. (Deliar Noer dalam Irfan A. Awwas, 2001: vii).

Setelah Indonesia merdeka, usaha pemberlakuan syariat Islam tidak juga berhenti. Ada yang dengan berangsur-angsur menegakkannya dalam kehidupan politik, seperti perjuangan diberlakukannya Piagam Jakarta di dalam Majelis Konstituante. Dan, terus-menerus diperjuangkan umat Islam secara politik dan kultural meski belum berhasil memberlakukan syariat Islam secara total. Kendati demikian, di pertengahan terakhir masa Orde Baru berkuasa, beberapa ketentuan syariat Islam sudah bisa diakomodir oleh negara (Deliar Noer dalam Irfan A. Awwas, 2001: vii).

Berakhirnya Orde Baru yang dilanjutkan dengan Orde Reformasi memperlihatkan dinamika baru tentang intensitas syariah dalam Negara berdasar atas Ketuhanan Yang Maha Esa. Banyak daerah di Indonesia memperjuangkan penerapan syariah di masing-masing. Daerah yang paling menonjol adalah Aceh karena diatur secara khusus, melalui otonomi khusus. Aceh lebih leluasa untuk menerapkan syariah dan memunculkan berbagai macam aturan daerah (qanun) untuk menerapkan syariah dimaksud. Sedangkan daerah-daerah lain mendapatkan tantangan dari adanya pemikiranpemikiran yang tidak memahami syariah. Sehingga muncul ungkapan perda syariah inkonstitusional, padahal berdasarkan konsep intensitas, ungkapan itu sendiri yang sebenarnya inkonstitusional.

Polemik penerapan syariah sepanjang sejarahnya membuktikan kebenaran informasi Tuhan yang membuat syariah itu sendiri. Bukankah Tuhan sudah memberikan begitu banyak informasi yang salah satunya mengandung arti: maka datanglah sesudah mereka, pengganti (yang jelek) yang menyianyiakan shalat dan memperturutkan hawa nafsunya, Maka mereka kelak akan menemui kesesatan (Terjemah Firman Tuhan Q.S. Maryam [19] ayat ke- 59). Adanya informasi Tuhan ini dihubungkan 
dengan polemik penerapan syariah dapat dipahami bahwa orang yang memperturutkan hawa nafsu (orang sesat) yang senantiasa menjadikan penerapan syariah sebagai polemik. Sebaliknya bagi orang beriman, penerapan syariah adalah solusi sebab satu prinsip yang dipegang teguh oleh orang beriman adalah sami'na wa atha'na (kami dengar wahai Tuhan dan kami taati syariah-Mu).

\section{PENUTUP}

\section{Kesimpulan}

Berdasarkan uraian sebelumnya dapat disimpulkan bahwa intensitas syariah di Negara berdasar atas Ketuhanan Yang Maha Esa merupakan suatu yang ideal dan mutlak untuk senantiasa diperjuangkan. Karena hanya dengan menjadikan syariah sebagai nilai ideal dan nilai operasional dalam seluruh penyelenggaraan Negara, Negara bisa mewujudkan tujuan luhurnya untuk membentuk suatu Pemerintah Negara Indonesia yang melindungi segenap bangsa Indonesia dan seluruh tumpah darah Indonesia dan untuk memajukan kesejahteraan umum, mencerdaskan kehidupan bangsa, dan ikut melaksanakan ketertiban dunia yang berdasarkan kemerdekaan, perdamaian abadi dan keadilan sosial. Adanya berbagai polemik dalam penerapan syariah menunjukkan kebenaran syariah itu sendiri dan adanya persoalan pada pribadi orang yang menjadikannya sebagai polemik.

\section{Saran}

Beberapa hal yang menjadi saran adalah; pertama, disarankan kepada segenap elemen bangsa untuk memahami intensitas syariah dan berupaya optimal menerapkannya dalam kehidupan; kedua, kepada pihak-pihak yang sekiranya keberatan dengan syariah- disarankan senantiasa berdo'a kepada Tuhan supaya Tuhan memberikan hidayah-Nya dan memberikan petunjuk ke jalan yang lurus; ketiga, kepada para pihak sekiranya ada yang acuh tak acuh kepada penerapan syariah-disarankan memohon dengan tulus kepada Tuhan agar Tuhan membukakan pintu hati sehingga bisa menjadi konsisten di jalur syariah.

\section{DAFTAR KEPUSTAKAAN}

al-Abudi, Muhammad ibn Nasir. 2000. Fi Indunisia Akbaru Biladil Muslima, Riyadh.

Al-Qur'an dan Terjemahnya

Awwas, Irfan A.. 2001. Risalah Kongres Mujahidin dan Penegakkan Syariah Islam. Yogyakarta: Wihdah Press.

Departemen Pendidikan Nasional. 2003. Kamus Besar Pendidikan Nasional, Jakarta: Balai Pustaka.

Ensiklopedi Hadis Kitab 9 Imam, Lidwa Pustaka Publisher

Ka'bah, Rifyal. 2005. Politik dan Hukum dalam Al-Qur'an, Jakarta: Khairul Bayan Sumber Pemikiran Islam.

Mudawam, Syafaul. 2012. Syariah-FiqihHukum Islam Studi tentang Konstruksi Pemikiran Kontemporer, Asy-Syir'ah, Jurnal Ilmu Syariah dan Hukum, Vol. 46, No. II, Juli-Desember.

Undang-Undang Dasar Negara Republik Indonesia Tahun 1945.

Undang-Undang Nomor 12 Tahun 2011 Tentang Pembentukan Peraturan Perundang-Undangan. 
Website alquranterjemah.com

Yunus, Nur Rohim. 2015. Penerapan Syariat Islam Terhadap Peraturan Daerah dalam Sistem Hukum Nasional Indonesia, Hunafa: Jurnal Studia Islamika, Vol. 12, No. 2, Desember.
Yusdani. 2006. Formalisasi Syariat Islam dan Hak Asasi Manusia di Indonesia, alMawarid Edisi XVI. 